\title{
C. difficile associated diarrhoea-don't blame community or norovirus
}

\author{
N Damani", R Trudy, M Markey, S Wallace \\ From International Conference on Prevention \& Infection Control (ICPIC 2011) \\ Geneva, Switzerland. 29 June - 2 July 2011
}

\section{Introduction / objectives}

C. difficile associated diarrhoea (CDAD) has been recognised as the most common cause of hospital acquired diarrhoea. At the beginning of 2008, our Trust's Infection Prevention and Control developed a comprehensive intervention plan to reduce the number of CDAD cases.

\section{Methods}

Implementation of multi-modal intervention which included, early diagnosis, prompt isolation, introduction of hand hygiene, implementation of antibiotic stewardship programme, education and training, enhanced environmental cleaning, and feed back of surveillance (outcome and process) proved very effective in reducing the total no. of CDAD.

\section{Results}

As a result of multi-modal interventions, the total no. of CDAD case were reduced from 286 in 2008 to only 38 cases in 2010. We also carried out Root Cause Analysis of all cases of CDAD and found that only $15 \%$ cases were 'true' community cases. In addition, during the winter of 2009, our wards were affected with outbreaks of norovirus and we tested all norovirus outbreak specimens for C.difficile toxin. However, unlike previous years, we did not see a rise in the number of new cases of C.difficile infection and for the first time, we were not able to find even a single case that was positive both for norovirus and C.difficile toxin.

\section{Conclusion}

We concluded that the health care facilities are the major sources of CDAD. We conclude that once you start to control CDAD in hospitals, the number of cases of $C$ difficile will reduce both in hospital and

Infection Prevention and Control, Craigavon Area Hospital, Portadown, UK community. We also conclude that isolation of C.difficile toxin from specimens submitted for norovirus outbreak may detect patient with C.difficile colonization ${ }^{1}$.

1. Damani NN, Wallace S. Does viral gastroenteritis really increase the reports of Clostridium difficile infection? J of Hosp infect 2011; 77; 171-172.

\section{Disclosure of interest}

None declared.

Published: 29 June 2011

doi:10.1186/1753-6561-5-S6-P186

Cite this article as: Damani et al: C. difficile associated diarrhoea-don't blame community or norovirus. BMC Proceedings 2011 5(Suppl 6):P186.
Submit your next manuscript to BioMed Central and take full advantage of:

- Convenient online submission

- Thorough peer review

- No space constraints or color figure charges

- Immediate publication on acceptance

- Inclusion in PubMed, CAS, Scopus and Google Scholar

- Research which is freely available for redistribution

Submit your manuscript at www.biomedcentral.com/submit
() Biomed Central

\section{Biomed Central}

